\title{
Water resource accounting for Uganda: use and policy relevancy
}

\author{
Nicholas Kilimani*, Jan van Heerden and Heinrich Bohlmann \\ Department of Economics, University of Pretoria, Private Bag X20, Hatfield 0028- South Africa. \\ *Corresponding author.E-mail: n_kilimani@yahoo.com;nick.kilimanil@gmail.com;nick.kilimani@up.ac.za
}

\begin{abstract}
This paper uses the system of economic and environmental accounting for water to demonstrate how the water sector interacts with the social-economic sectors of the economy. Furthermore, it reviews the existing institutional and policy framework in Uganda, and proposes an analytical framework which can be used to provide sound intersectoral planning in order to achieve sustainable water resource use. The proposed framework also articulates how outcomes of water policies and social-economic policies can be analyzed. In Uganda, the uneven distribution of water resources both in space and time, poses constraints to economic activity particularly in the water-scarce regions of the country. The problem is being exacerbated by the increasingly erratic rainfall and rising temperatures. The accounting results show that the current level of water use within the economy is less than the available quantity. In this regard, there is room for the development of mechanisms to increase its utilization. This would serve to mitigate the scarcity especially of water for production which primarily emanates from climate variability. This in turn affects the performance of the economy, as key sectors such as agriculture are rainfall-dependent.
\end{abstract}

Keywords: Institutional framework; Policy analysis; SEEAW; Water accounting

\section{Introduction}

This paper uses an analytical framework which demonstrates how water resources interact with the economic system. It also proposes a framework for analyzing the interaction between the water sector policies and the policies of other sectors of the economy. The World Commission on Sustainable Development (WCED) recognizes the close link between the environment and the economy where it stresses that:

'..no region in the world faces separate environmental challenges, development challenges or energy challenges. They are all one' (WCED, 1987). 
Hence, the existing challenges cannot be solved by fragmented institutions or policies. These call for trans-disciplinary competencies and approaches that are geared towards advancing a sustainable development agenda for economic growth and well-being (NEMA, 2010).

This study is motivated by the prevailing environmental-economic challenges faced by Uganda to investigate the level of use vis-à-vis the amount of water resources available in the economy. In addition, a framework for policy analysis is developed in order to demonstrate how water resource policies can be linked with other social-economic policies in a national development planning process, with a view to ensuring sustainable use of the existing water resources in an economy. This study is vital since water resources are increasingly coming under threat from climatic variability which is manifesting in the form of increasing frequency and severity of climatic shocks as well as shifts in temperature and rainfall patterns (IPCC, 2007; Hepworth \& Goulden, 2008).

For the case of Uganda, studies on water resources have largely focused on the hydrological dynamics with little or no attempt to link water resources and the rest of the economy (see Sutcliffe \& Parks, 1999; Awange et al., 2008; Nyenje \& Batelaan, 2009; Kizza et al., 2009; Swenson \& Wahr, 2009; Nsubuga et al., 2011, 2014a, 2014b; Smith \& Semazzi, 2014). Those which attempt to include other aspects of water resources and the economy focus on river or lake basins, of which some are transboundary in nature (see e.g., Awange \& Ong'ang'a, 2006; Kayombo \& Jorgensen, 2006; IWMI, 2012). In fact, IWMI (2012) cite the Nile basin as wide and complex, with varying dimensions with respect to poverty, productivity, vulnerability, water access and socio-economic conditions. It therefore recommends that further in-depth research and local analysis be undertaken in order to bolster further understanding of issues and systems, with a view to designing appropriate interventions.

This study seeks to add to the literature on water resource accounting and integrated policy analysis at a national level. In addition, it seeks to contribute to the very limited evidence on water resource accounting and policy analysis from a developing country perspective, amid threats of water scarcity. This is important because Uganda, like most developing countries, has no established water accounts and yet, as a developing country, it is susceptible to the adverse effects of water scarcity. This is because a considerable proportion of its economic output is rooted in climate-sensitive sectors such as agriculture. Miguel et al. (2004) found that rainfall shocks constitute a good proxy for household income shocks in Uganda. Therefore, the development of national water accounts provides a vital tool for economy-wide water resource planning at a national level. This can result in interventions which are geared toward efficient use of the available water resources, and a reduction in the dependency on rainfall for the water-dependent sectors of the economy.

According to the Organization for Economic Co-operation and Development (OECD, 2008), over half of the world's population will be living under water scarcity due to the effects of climate change by 2030. Rainfall, which is a key input into the hydrological cycle, is increasingly showing significant variations both regionally and globally (Nsubuga et al., 2014a). Such variations can have adverse effects on the availability of water resources especially for those water sources whose recharge is derived from it (Ngongondo, 2006). Furthermore, a number of sectors of most developing economies are dependent upon rainfall whose seasonality is increasingly becoming volatile and intensity is reducing. This has the effect of reducing water availability through reduction in the recharge of both surface and groundwater sources. River basins which depend on a monsoon-type regime such as the Nile - one of Uganda's major surface water sources - and the Ganges in India, have been cited as being vulnerable to changes in the seasonality of run-off. This has adverse ramifications for water resource availability in countries that lie within these basins (World Bank, 2012). In the case of 
Uganda, there exists a contrast in seasonality between the sub-basins that lie above and below latitude $2{ }^{\circ} \mathrm{N}$ (i.e., the northern and southern sub-basins) (see Nsubuga et al., 2014a, p. 284).

It is therefore important to closely monitor the available water resources in order to ensure their proper management and utilization. In Uganda, $80 \%$ of the total catchment of Lake Victoria - the largest basin in East Africa - relies on direct rainfall while the remaining $20 \%$ is derived from river and underground discharges (Awange et al., 2008). Studies of rainfall fluctuations in Uganda have demonstrated that total rainfall during the March to May season, and the number of wet days in a number of weather stations, are decreasing (see Nsubuga et al., 2011). FEWSNET (2012), in a study of climate trends in Uganda, showed that the period 1975-2009 witnessed an increase in temperature and a reduction in rainfall. Average temperatures in Uganda are projected to increase by up to $1.5^{\circ} \mathrm{C}$ in the next two decades (LTS International, 2008). In fact, increases in the temperature and pollution of surface water sources tend to increase the abundance of hazardous toxins in the water. Consequently, domestic water supply, the ecology of surface water sources and aquatic life are threatened. There is already evidence of such pollution in some bays of Lake Victoria (LTS International, 2008).

Furthermore, changes in rainfall patterns and increases in temperature are swiftly translating into yield reductions in many crops (Glantz et al., 2009). Such changes present adverse effects on the economy to the extent that they affect export performance, foreign exchange earnings and employment. It is therefore evident that an intricate relationship exists between the water resources and other sectors of the economy. Hence, the water sector policies and those of other sectors have feedback loops on each other. This therefore calls for policy analysis to be carried out in an integrated manner. To demonstrate this inter-relationship, water is primarily a critical resource for the agricultural sector. In turn, agriculture is a major source of employment; it supplies primary inputs to other sectors; it provides food security to households, and is a major source of export earnings (MFPED, 2011). However, the increasingly unreliable rainfall, coupled with the uneven distribution of water sources, is threatening the sustainability of social-economic activity in the country.

\subsection{Objectives}

This paper seeks to:

(a) examine the state of water resources in Uganda;

(b) undertake national water accounting using the system of economic and environmental accounting for water (SEEAW) framework;

(c) propose a framework for policy analysis of integrated water resources management (WRM);(d) highlight policy issues which arise from the analysis.

The rest of the paper is organized as follows. Section 2 provides a situational analysis of water resources in the country, a review of the institutional and policy framework is presented in Section 3 , and the methodological steps for resource accounts development and findings are articulated in Section 4. A framework for linking analysis of water policies and other social-economic policies is developed in Section 5, and Sections 6 and 7, respectively, provide the conclusions and emerging issues. 


\section{Situational analysis of water resources in Uganda}

This section provides insights into the state of water resources in Uganda with the aim of providing basis for the need to develop a link between water resources and the economy. Approximately $25 \%$ of theacountry's surface area $\left(241,000 \mathrm{~km}^{2}\right)$ is covered by lakes and rivers. From a biophysical perspective however, much of the country experiences high rates of potential evaporation - approximately $75 \%-$ within the range 1,350-1,750 mm/year (DWRM, 2011). Similarly, Van Steenbergen \& Luutu (2012) indicate that a large proportion of rainfall (approximately 70-90\%) goes back into the atmosphere through evapotranspiration. Only a small proportion of this rainfall stays on the land surface and contributes to surface flow via run-off, and to groundwater recharge via infiltration through the unsaturated zone. They further note that, given the nature of the aquifers, groundwater is recharged mostly during heavy rainfall events. As such, these high rates of evaporation have implications for economic activity with regard to soil moisture for crop production, groundwater recharge, and rangeland productivity (DWRM, 2011).

The country receives a mean annual rainfall of 1,200 $\mathrm{mm}$. However, only the Lake Victoria shores and the mountainous areas (Mt Rwenzori, Mt Elgon, and the Kisoro-Kabale region) experience, on average, an annual rainfall surplus (i.e., annual rainfall that exceeds potential evaporation). Average annual rainfall exceeds potential evaporation in only $10.6 \%$ of the land area. In $20 \%$ of the country, the average rainfall deficit is less than $200 \mathrm{~mm}$ per annum, while another $35 \%$ is in the range of $200-400 \mathrm{~mm}$ (DWRM, 2011). In addition, the north-eastern region (approximately $35 \%$ of the country) experiences an annual rainfall deficit exceeding $400 \mathrm{~mm}$. However, DWRM (2011) notes that 'a rainfall deficit does not necessarily translate into an equal amount of moisture deficit during plant growth, as traditional agricultural production systems are well adapted to these seasonal weather patterns' (DWRM, 2011, p. 8). This observation notwithstanding, empirical evidence suggests that the prevalence of rainfall deficits can have adverse implications for economic performance (Glantz et al., 2009).

In terms of surface water, River Nile flows exceed $25 \mathrm{~km}^{3}$ per year, coupled with large combined storage capacities in the lakes: Victoria, Albert, Edward and Kyoga (DWRM, 2011, p. 7). However, while Uganda is generally endowed with water resources, social-economic activity still continues to depend on rainfall. As noted earlier, studies show that rainfall is on the decline and this is likely to pose social-economic challenges in the medium to long-term. In fact, this view has been reinforced by recent experiences in the areas of demography and climate. Specifically, the country is registering rapid population growth of $3.2 \%$ and increasing climatic volatility which is being attributed to climate change (MFPED, 2011, p. 80) ${ }^{1}$. Droughts have become frequent and severe, thereby posing a threat to the prospects of stable long-term economic performance.

Findings from FEWSNET (2012) show that the spatial pattern of warming corresponds largely to the areas associated with reduced rainfall. Temperatures are reported to have increased by up to $1.5^{\circ} \mathrm{C}$ across much of the country, with typical rates of warming of approximately $0.2{ }^{\circ} \mathrm{C}$ per decade. This trend is envisaged to continue as well as the expansion of warm areas in the medium to long-term, as the earth's temperature continues to rise. The western and north-western regions of the country are cited as the most affected by these changes. The rising temperature has specifically been cited as a threat to coffee production, a key cash crop for the economy. Therefore, the effects of a warmer climate

\footnotetext{
${ }^{1}$ The country is increasingly experiencing severe and regular waves of hydrologic droughts in the different regions.
} 
are likely to exacerbate the impact of the decreasing rainfall and periodic droughts. This would ultimately have an adverse impact on the economy. Generally, the FEWSNET (2012) findings show that the country is becoming drier and hotter.

Current water consumption is estimated at $21 \mathrm{~m}^{3}$ per capita (NPA, 2010). However, it is projected to rise gradually to approximately $30 \mathrm{~m}^{3}$ per capita by 2035 (MWE, 2009). Table 1 presents the growth in per capita water availability against the conventional benchmarks for water stress.

In Table 1, the Falkenmark \& Widstrand (1992) indicator of national water scarcity is used to compare the available per capita renewable water in Uganda against the water stress threshold values of 500, 1,000 and $1,700 \mathrm{~m}^{3} /$ per capita/year. Based on this criterion, countries or regions are considered to be facing absolute water scarcity if their renewable water resources are $<500 \mathrm{~m}^{3}$ per capita; chronic water shortage if renewable water resources are between 500 and $1,000 \mathrm{~m}^{3}$ per capita; and regular water stress if resources are between 1,000 and $1,700 \mathrm{~m}^{3}$ per capita. According to this criterion, Uganda will be a water stressed country by 2020 .

However, it is critical to note that, although this measure has its merits, it is based on an oversimplified perspective of the water situation of a country. This is because the approach is largely based on estimates of the number of people that can reasonably live with a certain unit of water resources (see Falkenmark, 1984; FAO, 2012). This approach ignores critical local factors that determine access to water, as well as the feasibility of solutions aimed at water provision in the different locations. Most importantly, it does not account for the prevailing climatic conditions; inter- and intra-annual variability of water resources and environmental water requirements which tend to vary from region to region and also affect water availability (Molle \& Mollinga, 2003; FAO, 2012).

In the case of Uganda, averages at the country level may be indicative but not particularly meaningful, since the country has strong regional variations in the spatial distribution of water resources. What is vital to note is that even with this simplified basic indicator, the country will be water stressed by 2020 . In fact, if we factor in the adverse effects of climatic variability on water resource availability via the interference with the recharge system and the rising temperatures, it suggests that the stress levels will become evident faster than the projections reveal. In addition, the level of severity will be more acute than otherwise thought. Additional pressure on water availability is bound to emanate from economic growth, population

Table 1. Water demand projections against the conventional benchmarks for water stress ${ }^{\mathrm{a}}$.

\begin{tabular}{|c|c|c|c|c|c|}
\hline \multirow[b]{2}{*}{ Year } & \multicolumn{3}{|c|}{ Water demand projections (millions $\mathrm{m}^{3}$ ) } & \multicolumn{2}{|l|}{ Benchmarks for water stress } \\
\hline & $\begin{array}{l}\text { Population } \\
(' 000)\end{array}$ & $\begin{array}{l}\text { Total water } \\
\text { demand }\end{array}$ & $\begin{array}{l}\text { Available water per } \\
\text { capita }\left(\mathrm{m}^{3}\right)\end{array}$ & $\begin{array}{l}\text { Annual renewable fresh water per } \\
\text { capita }\left(\mathrm{m}^{3}\right)\end{array}$ & Stress level \\
\hline 2009 & 32,864 & 707 & 2,171 & $>1,700$ & $\begin{array}{l}\text { Occasional water } \\
\text { stress }\end{array}$ \\
\hline 2015 & 40,141 & 994 & 1,740 & $1,000-1,700$ & $\begin{array}{l}\text { Regular water } \\
\text { stress }\end{array}$ \\
\hline 2020 & 47,088 & 1,266 & 1,480 & $500-1,000$ & $\begin{array}{l}\text { Chronic water } \\
\text { shortage }\end{array}$ \\
\hline 2035 & 72,691 & 2,113 & 896 & $<500$ & $\begin{array}{l}\text { Absolute water } \\
\text { scarcity }\end{array}$ \\
\hline
\end{tabular}

${ }^{\mathrm{a}}$ Conventional definitions of water stress following Falkenmark \& Widstrand (1992).

Source: MWE (2009); FAO (2012);UNDESA-Population Division of the Department of Economic and Social Affairs of the United Nations Secretariat, World Population Prospects: The 2012 Revision, http://esa.un.org/unpd/wpp/index.htm. 
growth, and rapid urbanization. A combination of these factors is likely to lead to the extraction of significant amounts of water, thereby further contributing to water scarcity.

\section{Legal institutional and policy framework for the water sector in Uganda ${ }^{2}$}

The national policy objectives for the water and environment sector have been developed with a view to ensuring WRM, domestic water supply, sanitation, and water for production (WfP). Specifically, the framework is designed to:

(a) manage and develop the water resources in an integrated and sustainable manner, in order to ensure an adequate quantity and quality of water for all social and economic needs of current and future generations, with the active involvement of all stakeholders;

(b) achieve sustainable provision of safe water within easy reach, and hygienic sanitation facilities based on management responsibility and ownership by the users, to $77 \%$ of the population in rural areas and $100 \%$ of the urban population by 2015 with $80-90 \%$ effective use and functionality of facilities; and

(c) develop and efficiently use water supply for production (agriculture, irrigation, livestock, aquaculture, rural industries, hydropower, and tourism).

Overall sector coordination is through the Water and Environment Sector Working Group (WESWG). Under the water and sanitation sector, there exist the following components: WRM; rural water supply (RWS); urban water supply and sewerage (UWSS); WfP; and sanitation (MWE, 2009). The institutional framework for the water and sanitation sector comprises a number of organizations and stakeholders at national, district, and community levels as illustrated in Figure 1.

\subsection{Policy, legal, and strategic framework}

The management and development of water resources in Uganda is governed by the (1995) Constitution of the Republic of Uganda. This is further supported by the Uganda Water Action Plan (1995) and the National Water Policy (1999) which sets out the overall policy framework. The National Water Policy seeks to facilitate an integrated approach to the management of water resources in a manner that is sustainable and optimal for the country. The approach is informed by the recognition of the social value of water, while at the same time giving adequate attention to its economic value. There are other policies designed to play an auxiliary role, such as the National Environment Management Policy (1994); the Wetlands Policy (1995); the National Land Use Policy; the National Health Policy and Health Sector Strategic Plan (1999); the National Environmental Health Policy (2005); the School Health Policy (2006); and the National Gender Policy (1997).

The key legal frameworks that guide the management of the sector include the:

(a) Constitution of the Republic of Uganda (1995);

\footnotetext{
${ }^{2}$ Section draws from MWE (2009) this.
} 


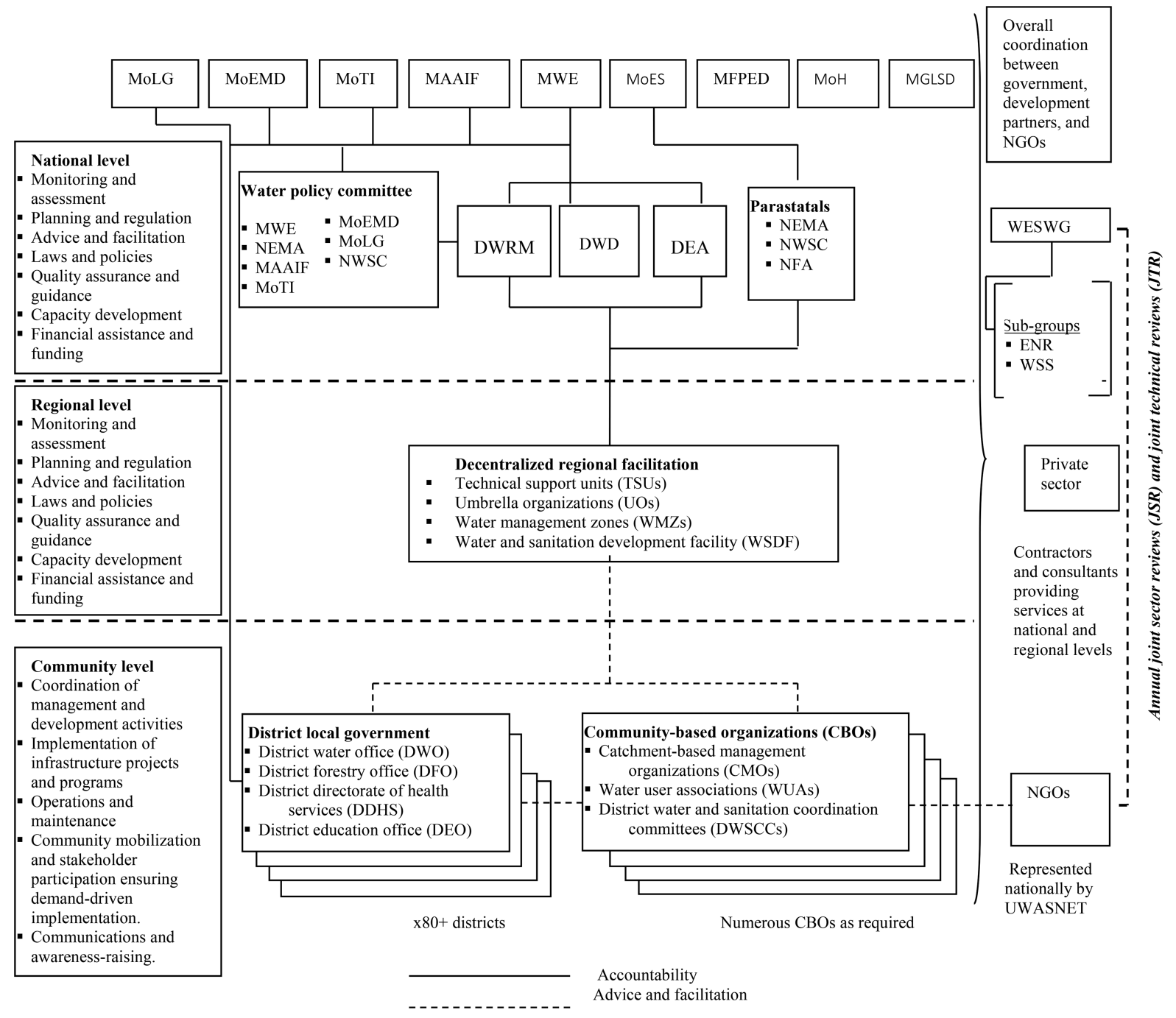

Fig. 1. Institutional configuration of the water sector in Uganda. Source: MWE (2009). Notes: MoLG: Ministry of local government; MoEMD: Ministry of energy and mineral development; MoTI: Ministry of trade and industry; MAAIF: Ministry of agriculture, animal industry and fisheries; MWE: Ministry of water and environment; MFPED: Ministry of finance, planning and economic development; MoH: Ministry of health; DWRM: Directorate of water resources management; DWD: Directorate of water development; DEA: Directorate of environmental affairs; NEMA: National environment management authority; MGLSD: Ministry of gender, labor and social development; NWSC: National water and sewerage corporation; NFA: National forestry authority; WESWG: Water and environment sector working group; ENR: Environment and natural resources; WSS: Water supply and sanitation; UWASNET: Uganda water and sanitation NGO network.

(b) Water Act, Cap 152;

(c) Environment Act, Cap 153;

(d) National Water and Sewerage Corporation (NWSC) Act, Cap

317;(e) Local Governments Act, Cap 243;

(f) Land Act, Cap 227; 
(g) Public Health Act (1964);

(h) Children Statute (1996);

Furthermore, the regulations and standards that are in place to guide users include the:

(a) Water Resources Regulations (1998);

(b) Water Supply Regulations (1998);

(c) Water (Waste Discharge) Regulations (1998);

(d) Sewerage Regulations (1999);

(e) Waste Management Regulations (1999);

(f) Environmental Impact Assessment Regulations (1998);

(g) National Environment (Standards for Discharge of Effluent into Water or on Land) Regulations (1999); and

(h) National Environment (Waste Management) Regulations

(1999).

3.1.1. Strategies and guidelines. The water sector also includes a number of guidelines and strategies such as:

- The Water Sector Pro-poor Strategy (2006), Directorate of Water Development (DWD);

- District Water and Sanitation Conditional Grant Guidelines, December (2001);

- RWS and Sanitation Handbook for Extension Workers (2002);

- Framework for Technical Support Units, November (2001);

- Community Based Maintenance System, DWD.

- National Water Quality Management Strategy (2006);

- The Plan for Modernization of Agriculture (2000);

- The country's Strategic Interventions Programme for Export Promotion;

- The School Health Minimum Requirements (2000);

- The Infant and Maternal Mortality Strategy;

- The Water and Sanitation Gender Strategy (2003);

- The Strategy for 'Water and Sanitation for Emergency Response';

- The Community Empowerment Strategy, Ministry of Gender, Labor and Social Development (MGLSD);

- The National Sanitation Guidelines, 2001, Ministry of Health (MoH);

- The Kampala Declaration on Sanitation (KDS) (1997);

- The Sanitation Memorandum of Understanding (2001) between Ministry of Water Lands and Environment (MWLE), MoH and Ministry of Education and Sports (MoES);

- Long-term Strategy for WSS Services in Small Towns (2003);

- Long-term Strategy for WSS in Rural Growth Centres (2003);

- National Water Quality Management Strategy (2006).

\subsection{Reform measures in the water and sanitation sector}

Since 1998, the Government of Uganda, with the support of the Development Partners, has taken steps to reform four different sub-sectors, namely: rural water and sanitation (RWS); UWSS; WfP; and WRM (MWE, 2009). In line with the developed sector investment plans, a geographical 
information system-based water and sanitation sector integrated investment tool was developed in 2007. This tool was intended to provide better insight into current and planned sector investments through enhanced monitoring and evaluation, identification of priorities and the determination of areas with development deficits, as well as detect areas where investments would have the highest impact.

The system was also designed to help visualize the spatial disparities across the country in order to ensure transparent and equitable resource allocation and performance. The reforms have been put in place with a view to minimizing duplication and contradictions in mandates of the different institutions; to address current issues such as population growth, shifting priorities towards WfP in order to contribute to prosperity for all; increased incidence of climatic variability; the impact of WRM on the economy; and the operationalization of decentralized integrated water resources management (IWRM) strategies at catchment level.

\section{Water resource accounting}

This paper uses the system of environmental and economic accounting for water (SEEAW) to account for the available supply and use of water resources. The SEEAW framework makes possible the link between water resources and the economy because the water supply and use tables (SUTs) have the same structure as the social accounting matrix (SAM). This suggests that economic policy analysis through integrated natural resource modeling is possible. The SEEAW ${ }^{3}$ is a comprehensive water accounting system that has been developed with the objective of standardizing concepts and methods in water accounting (UN, 1993; UNSD, 2012). It provides a conceptual framework for organizing economic and hydrological data thereby permitting a consistent analysis of the contribution of water to the economy and the impact of the economy on water resources (FAO, 2012). In fact, Dost et al. (2013) have developed an augmented integrated water accounting framework where they employ remote sensing data to build on a combination of existing systems and approaches. They argue that their approach to water resource accounting is easily applicable even in ungauged and poorly gauged basins. This is particularly the case for most developing regions of the world.

These accounts are vital to furnish information to policy-makers about the impact of current economic policies and growth patterns on the environment's resources. In this way, judgment can be made as to whether or not such policies are sustainable. In addition, information from these accounts helps to gauge the impact on the economy of policies taken for environmental reasons. Finally, one of the fundamental aims of this accounting framework is to assess how much economic 'growth' as it is conventionally measured, is actually capital consumption due to resource depletion (World Bank, 2006, cited in FAO, 2012).

When water is abstracted and processed, it is considered a product, as it enters into the economic sphere. This product can be delivered to other industries or to final consumers. When water is no longer useful in its current state, it is considered to be a residual. Some flows of residuals are recorded within the economy (for example, the routing of waste water to treatment plants) but, ultimately, all residuals are returned to the environment (see Figure 2). These flows do enter the economy, hence the return of water to the environment is recorded as a residual flow. In the case of Uganda, water used for hydro-electricity generation and the water extracted by agriculture for irrigation is considered as water returned to the hydrological system.

\footnotetext{
${ }^{3}$ See www.emwis.net/thematicdirs/glossaries/system-environmental-economic-accounting-water.
} 


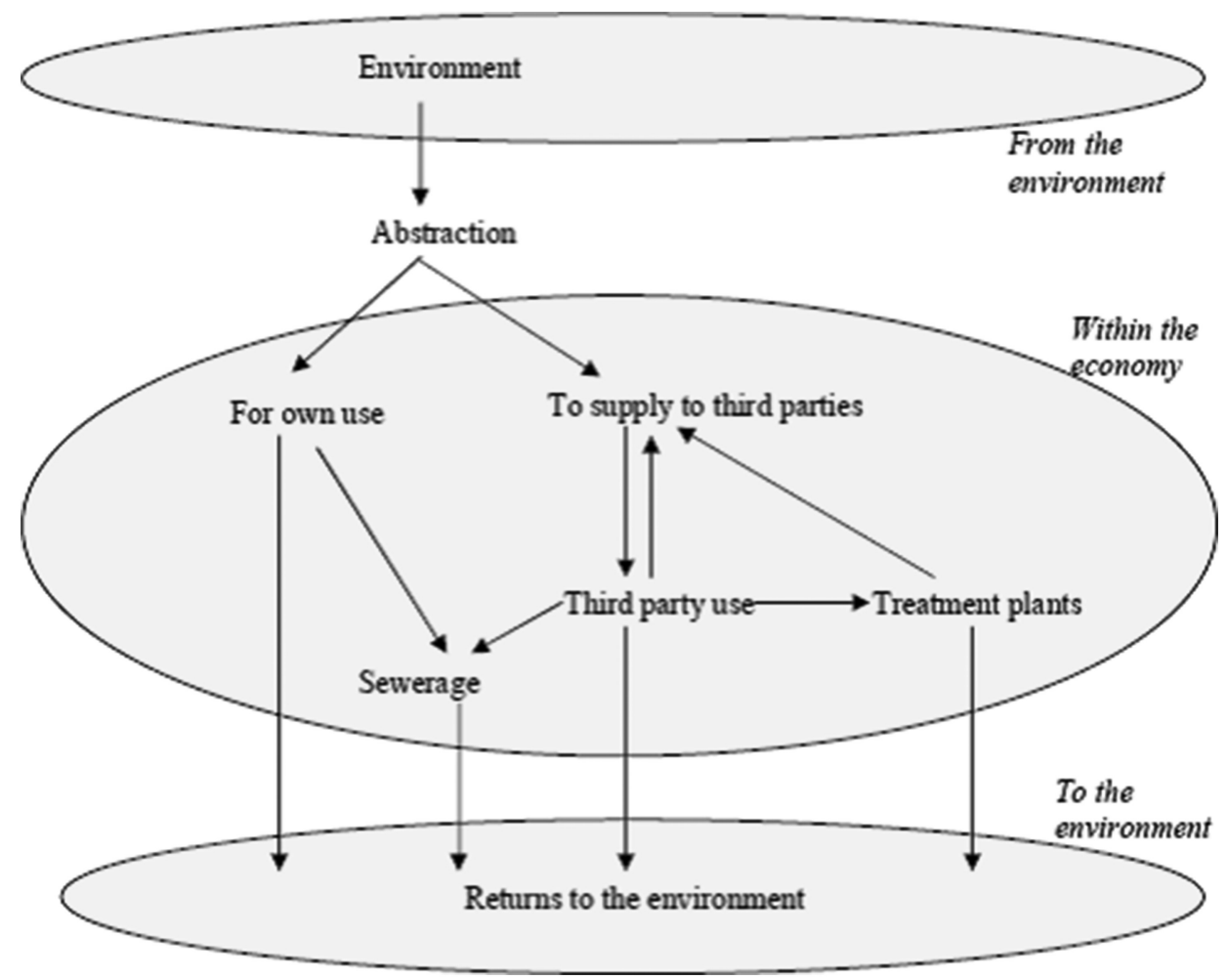

Fig. 2. Schematic flow of water resources. Source: Adopted from UN, IMF, IBRD and OECD (2003).

\subsection{Data}

Macroeconomic data was obtained from the Ministry of Finance Planning and Economic Development (MFPED) and the Uganda Bureau of Statistics. Water data was obtained from the Directorate of Water Resources Management (DWRM) and the Small Towns Water and Sanitation Programme (STWSP) under the Ministry of Water and Environment (MWE). Other data was obtained from the NWSC as well as the AQUASTAT database published by the Food and Agricultural Organization (FAO).

\subsection{Development of the water accounts}

In this section, the water accounts are developed using the SEEAW. The procedure entails partitioning the physical supply and use tables (PSUT) by their key components. In this paper, the accounts are adapted to integrate the environment and the economy ${ }^{4}$. The following components are included in order to reflect the key elements which are at the core of WRM in Uganda:

- From the environment: This is the source of all water resources and the ultimate repository to which all used and non-used water resources return.

\footnotetext{
${ }^{4}$ See Eurostat (2014), subsection 2.1.2, for an exposition of the framework for developing the PSUT.
} 
- Mean annual run-off (MAR): this receives water from the environment and redistributes to surface water and groundwater and back to the environment. This component is presented as part of surface water and groundwater yield by the DWRM.

- Surface water yield: collects from MAR and redistributes to available yield;

- Groundwater: sources are replenished by MAR and contribute to available yield;

- Soil water: collects precipitation from MAR to support evapotranspiration activities through natural and cultivated agriculture. This is accounted for under groundwater;

- Consumption: measured as water that is not returned to water bodies because it has either been absorbed by plants (crop water), livestock, humans (households) or industry. This component is presented accordingly in the accounts.

\subsection{Results and analysis}

The resource flow matrix is an input-output table that describes supply and use transactions in one table. Water users are aggregated in the water statistics in order to correspond to particular categories according to how water is supplied to these users. From the flow matrix, the main source of irrigation water to agriculture is from surface water while water supply to households, crops and fisheries is from the distribution agencies as well as other ground and surface water. The industrial sector is taken to be mainly supplied by the distribution agencies since there is no official data on abstraction for own use (see Tables 2-4).

From the accounts, the key indicators (in millions of $\mathrm{m}^{3}$ ) are obtained from the developed water accounts from which a water balance model is derived. These key indicators follow the rules of the SEEAW. The balance between water flows is expressed as:

Total abstraction $(4,511)+$ Use of water received from other economic units $(83.4)=$ Supply of water to other economic units $(83.4)+$ Total returns $(336)+$ Water consumption $(4,175)$.

Since total water supply to other economic units equals the total water use received from other economic units, the identity can be rewritten as:

Total abstraction $(4,511)=$ Total returns $(336)+$ Water consumption $(4,175)$

\subsection{Summary of findings from the resource accounting}

Flows from the environment to the economy are estimated at 43.2 billion $\left(10^{9}\right) \mathrm{m}^{3}$. Agriculture accounts for $63 \%$ of total water use with $21.2 \%$ going to livestock, $18.4 \%$ to irrigation, $47.5 \%$ for crops, and $13 \%$ to fisheries. Industry accounts for $4 \%$ of total water use in the economy while households consume $20.4 \%$. Flows within the economy consist of supply water to other economic units via distribution (approximately 83.4 million $\mathrm{m}^{3}$ ) which accounts for a small part of total water use $(6.5 \%)$. This is evidence of the limited distribution of water in the country through the piped network. For instance, the NWSC and STWSP distribution network is limited to a few districts in the country and is confined largely to urban areas. Consequently, a large proportion of water use by economic agents is obtained from other sources such as rainwater harvesting, springs, deep wells, and boreholes.

The results show an estimated 38.6 billion $\mathrm{m}^{3}$ in water supply surplus. This suggests that there are available water resources that can be exploited for productive use. Subject to availability of more detailed data, future analysis will provide for a more accurate picture of the exact amount of surplus 
Table 2. Water supply table (millions of $\mathrm{m}^{3}$ ).

\begin{tabular}{|c|c|c|c|c|c|c|c|c|c|c|c|c|c|c|c|c|}
\hline & & & \multicolumn{4}{|c|}{ Agriculture } & \multirow[b]{2}{*}{ Energy $^{1}$} & \multirow[b]{2}{*}{ Industry } & \multirow{2}{*}{$\begin{array}{l}\text { DWR } \\
\text { (Total) }\end{array}$} & \multirow{2}{*}{ NWSC } & \multirow[b]{2}{*}{ STWSP } & \multirow[b]{2}{*}{ Govt } & \multirow[b]{2}{*}{ Hholds } & \multirow[b]{2}{*}{ RoW } & & \multirow{2}{*}{$\begin{array}{l}\text { Total } \\
\text { supply }\end{array}$} \\
\hline & & & Livestock & Irrigation $^{1}$ & Crops $^{1}$ & Fisheries & & & & & & & & & & \\
\hline & Total Abstractions & & & & & & & & & & & & & & 43,201 & $43,201^{a}$ \\
\hline \multirow[t]{2}{*}{$\begin{array}{l}\text { From the } \\
\text { environment }\end{array}$} & $\begin{array}{l}\text { From surface water } \\
\quad \text { (internal) }\end{array}$ & & & & & & & & & & & & & & 13,000 & 13,000 \\
\hline & $\begin{array}{l}\text { From ground water } \\
\text { (internal) }\end{array}$ & & & & & & & & & & & & & & 9,500 & 9,500 \\
\hline \multirow[t]{6}{*}{ S1 } & RoW (in transfers) & $\begin{array}{r}\text { From surface } \\
\text { water }(\mathrm{M})\end{array}$ & & & & & & & & & & & & & 8,700 & 8,700 \\
\hline & & $\begin{array}{c}\text { From surface } \\
\text { water }(\mathrm{X})\end{array}$ & & & & & & & & & & & & & 12,001 & 12,001 \\
\hline & & $\begin{array}{r}\text { From ground } \\
\text { water }(\mathrm{M})\end{array}$ & & & & & & & & & & & & & & \\
\hline & & $\begin{array}{l}\text { From ground } \\
\text { water }(\mathrm{X})\end{array}$ & & & & & & & & & & & & & & \\
\hline & & For own use & & & & & 80 & & & & & & & & & \\
\hline & & For delivery & & & & & & & 83.4 & 79.7 & 3.7 & & & & & \\
\hline \multirow{2}{*}{$\begin{array}{l}\text { Within the } \\
\text { economy }\end{array}$} & Total supply of water & & $174.1^{1}$ & $151^{\mathrm{k}}$ & $389^{j}$ & $105^{\mathrm{i}}$ & $80^{\mathrm{h}}$ & $46^{\mathrm{g}}$ & $83.4^{\mathrm{f}}$ & $79.7^{\mathrm{e}}$ & $3.7^{\mathrm{d}}$ & & $264.1^{\mathrm{c}}$ & $3,301^{\mathrm{b}}$ & & 4,594 \\
\hline & $\begin{array}{l}\text { Water supplied to } \\
\text { users }\end{array}$ & & & & & & & & 83.4 & 79.7 & 3.7 & & 264.1 & & & 348 \\
\hline \multirow[t]{2}{*}{ S2 } & Recycled water & & & & & & & & & & & & & & & \\
\hline & $\begin{array}{l}\text { Waste water to } \\
\text { sewerage }\end{array}$ & & & & & & & & & & & & & & & \\
\hline \multicolumn{17}{|c|}{ To the environment } \\
\hline \multirow[t]{6}{*}{ S3 } & Total residuals & & & & & & & & & & & & & & & \\
\hline & Waste water & & & & & & & & & & & & & & & \\
\hline & Returns from Irrigation & & & 151 & & & & & & & & & & & & \\
\hline & $\begin{array}{l}\text { Water supply for HEP } \\
\text { Leakages }\end{array}$ & generation & & & & & 80 & & & & & & & & & \\
\hline & Other returns to the en & vironment & & & & 105 & & & & & & & & & & \\
\hline & To the sea & & & & & & & & & & & & & & & \\
\hline Consumption & & & & & & & & & & & & & & & & 4,174 \\
\hline Total supply & & & 174.1 & 151 & 389 & 105 & 80 & 46 & 83.4 & 79.7 & 3.7 & & 264.1 & 3,301 & 43,201 & 43,201 \\
\hline
\end{tabular}

See Appendix 1 for explanatory notes on the data sources and table presentation. 
Table 3. Water use table (millions of $\mathrm{m}^{3}$ ).

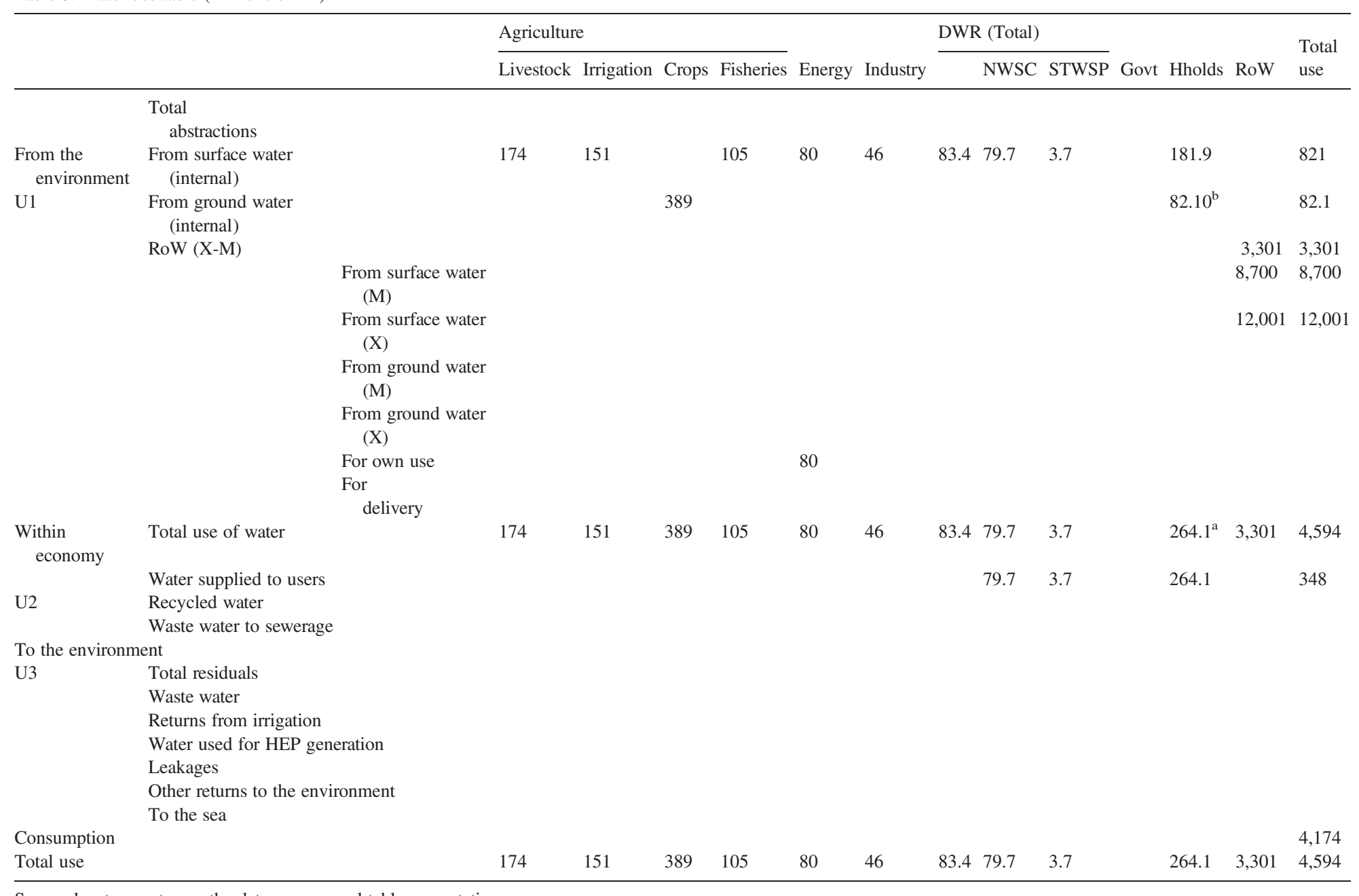

See explanatory notes on the data sources and table presentation. 
Table 4. Water flow matrix within the economy (millions of $^{3}$ ).

\begin{tabular}{|c|c|c|c|c|c|c|c|c|c|}
\hline Origin & Destination & $\begin{array}{l}\text { From surface } \\
\text { water (internal) }\end{array}$ & $\begin{array}{l}\text { From } \\
\text { groundwater } \\
\text { (internal) }\end{array}$ & $\begin{array}{l}\text { From other } \\
\text { water (rain } \\
\text { harvesting) }\end{array}$ & $\begin{array}{l}\text { RoW (in } \\
\text { Transfers) } \\
\text { From } \\
\text { surface } \\
\text { water (M) }\end{array}$ & $\begin{array}{l}\text { From } \\
\text { surface } \\
\text { water }(\mathrm{X})\end{array}$ & $\begin{array}{l}\text { From } \\
\text { groundwater } \\
\text { (M) }\end{array}$ & $\begin{array}{l}\text { From } \\
\text { groundwater } \\
\text { (X) }\end{array}$ & $\begin{array}{l}\text { For own } \\
\text { use }\end{array}$ \\
\hline \multicolumn{10}{|l|}{$\begin{array}{l}\text { From surface water } \\
\quad \text { (internal) }\end{array}$} \\
\hline \multicolumn{10}{|l|}{$\begin{array}{l}\text { From groundwater } \\
\text { (internal) }\end{array}$} \\
\hline & RoW (X-M) & & & & & & & & \\
\hline \multirow[t]{6}{*}{ RoW (in transfers) } & $\begin{array}{l}\text { From surface water } \\
\text { (M) }\end{array}$ & & & & & & & & \\
\hline & $\begin{array}{l}\text { From surface water } \\
\text { (X) }\end{array}$ & & & & & & & & \\
\hline & $\begin{array}{l}\text { From groundwater } \\
\text { (M) }\end{array}$ & & & & & & & & \\
\hline & $\begin{array}{l}\text { From groundwater } \\
\text { (X) }\end{array}$ & & & & & & & & \\
\hline & For own use & & & & & & & & \\
\hline & For delivery & & & & & & & & \\
\hline \multirow[t]{4}{*}{ Agriculture } & Livestock & & & & & & & & \\
\hline & Irrigation & & & & & & & & \\
\hline & Crops & & & & & & & & \\
\hline & Fisheries & & & & & & & & \\
\hline \multirow{3}{*}{\multicolumn{10}{|c|}{$\begin{array}{l}\text { Energy } \\
\text { Industrial } \\
\text { DWR }\end{array}$}} \\
\hline & & & & & & & & & \\
\hline & & & & & & & & & \\
\hline & NWSC & & & & & & & & \\
\hline & STWSP & & & & & & & & \\
\hline \multicolumn{10}{|l|}{ Govt } \\
\hline \multicolumn{10}{|l|}{ Hholds } \\
\hline \multicolumn{10}{|l|}{ RoW } \\
\hline \multicolumn{10}{|l|}{ Consumption } \\
\hline Total supply & & & & & & & & & \\
\hline $\begin{array}{l}\text { Total use of water } \\
\text { Surplus }\end{array}$ & & 0 & 0 & 0 & 0 & 0 & 0 & 0 & 0 \\
\hline
\end{tabular}


Agriculture

For delivery Livestock Irrigation Crops Fisheries Energy Industry DWR (total) NWSC STWSP Govt Hholds RoW Consumption Total supply

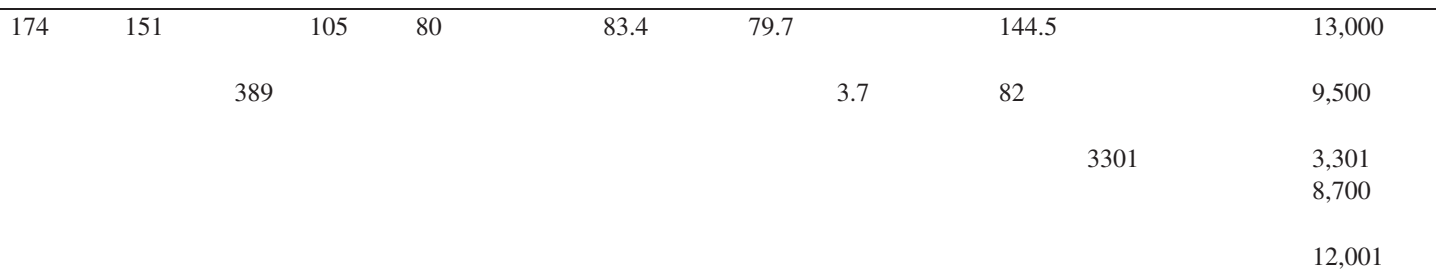

80

46

33.70

80

3.7

3.7

3,301

$4,174 \quad 4,174$

43,201

4,594

38,524 
water resources in the economy. This is because there is a need to net-out the threshold requirements for water that cannot be withdrawn from the environment as it is required for the ecosystems to function, for example, riverine habitat (instream flow requirements (IFR) $)^{5}$ thresholds vary from one country to another. Furthermore, depending on the technical hydrological assessments and recommendations, the existing water resources can be harnessed and utilized. In addition, it is necessary to account for other possible losses of water into the environment through deep seepage, river losses and evapotranspiration. These are technical hydrological issues which are outside the scope of this paper. However, it is clear from the results that the current level of water resources is adequate to address the existing economic challenges that emanate from water scarcity.

\section{Policy analysis and relevance of water resource accounting}

The existing institutional and policy framework in Section 3 clearly shows that there are multiple institutions charged with the management of water resources in Uganda. However, there is a need for an explicit connection between water sector policies and those of the social-economic sectors, since water resources are a key input into the country's economic and social sectors. This is even more pronounced for developing agro-based economies such as Uganda. Fortunately, the institutional framework provides for a key component such as WfP. Therefore, institutions which are charged with managing the productive sectors of the economy, i.e., the MFPED, the Ministry of Transport, the Ministry of Agriculture Animal Industry and Fisheries (MAAIF), and the Ministry of Tourism Trade and Industry need to link their development plans and policies with those of the water sector.

According to WCED (1987), achieving sustainable development is a goal worth pursuing for any economy. In this context, sustainable development is defined as a process in which the economy, environment and ecosystem of a region change in harmony such that there are improvements over time. Consequently, the development of a sound national water policy should relate the different development plans of the social-economic sectors in an explicit manner (see Simonovic \& Fahmy, 1999). In this paper, we propose a framework for policy analysis as a blueprint for explicitly relating development plans for the different social-economic sectors to those of the water sector (see e.g., Meadows et al., 1992). This framework can easily be adapted for similar studies on other countries.

This framework is designed to provide policy analysis of IWRM in a typical economy. The idea is to explicitly link a nation's development plans in the different social-economic sectors with the water resources. For example, agriculture, industry, households, hydro-electricity and navigation are key sectors that primarily depend on water. Development plans in these sectors involve a number of policy variables and inputs. Therefore, the interaction between the policy variables and their impacts are monitored through multiple indicators in the social-economic and ecological domains. Owing to the multiplicity of variables, the SEEAW framework used in the water resource accounting in Section 4 uses aggregated water data as do the existing approaches for analyzing the associated policy impacts. For instance, computable general equilibrium (CGE) models also use aggregation and hierarchical decomposition in order to simplify model development and data compression to a manageable size.

\footnotetext{
${ }^{5}$ In their study of the South African economy, King \& Crafford (2001) cite an estimate of 30\% of the MAR as the instream flow requirement.
} 
While the aggregation hides some of the temporal and spatial variability, it still preserves the fundamen-tal trends and helps to provide answers which are often demanded by policy-makers.

\subsection{Structure of the proposed framework}

The objective of this framework is to provide a mechanism for evaluation of both water policies and social-economic policies with a view to achieving the long-term social-economic development path for the country. In the framework, evaluation of policies can be undertaken using several indicators with respect to water availability, ecosystem quality, and economic growth (Simonovic \& Fahmy, 1999). The modeling approach utilizes hierarchical decomposition procedures to analyze interactions between a given sector and the water resources sector. For instance, agriculture can be decomposed into different sub-sectors. This is due to the very nature of its diversity with respect to cropping patterns, scale, and type of water used. The analytical framework is illustrated as follows:

$\mathrm{MS}_{i}(\mathrm{Ipw}, \mathrm{Ipo}, \operatorname{inp}, t) \rightarrow O_{t}\left(O_{\mathrm{env}}, O_{\mathrm{wat}}, O_{\mathrm{econ}}, O_{\mathrm{soc}}, t\right)$

where $\mathrm{MS}=$ sector model; $i=$ sector model identifier; Ipw = policy input variable controlled by the MWE; Ipo = policy input variable controlled by other institutions; Inp $=$ non-policy input variable, $t=$ time; $O=$ output vector; $O_{\text {env }}=$ environmental indicators; $O_{\text {wat }}=$ water availability indicators; $O_{\text {econ=economic indicator; } O_{\text {soc }=} \text { social indicators. }}$

There are many policy variables involved in a given sector, determined by a given development plan. Furthermore, the water supply variables are controlled by the MWE, while the demand-side policy variables and inputs are controlled by other institutions in other sectors. In most cases, all policy variables are dynamic in nature. Conversely, non-policy variables are deterministic with given values over the planning period. Table 5 proposes a series of possible variables that can be considered in policy analysis under the different sectors. It is worth noting that the choice of which variables are policy or non-policy depends on the structure of the economy, the existing development plan and the prevailing institutional, legal, and policy framework.

The interaction between policy variables and their impacts are monitored through multiple indicators in the social, economic, and ecological domains. Owing to the aggregation procedures, the model outputs should be taken as indicators and not precise measures of impacts of different scenarios. Nonetheless, these procedures have been scientifically considered as satisfactory for policy analysis. The proposed indicators for policy evaluation are highlighted in Table 6. Evaluation is based on multiple criteria and this is reflected in the proposed indicators.

Once the policy variables and outputs have been identified, the final step is to undertake simulation of policy alternatives. Analysis can be undertaken using dynamic mathematical programming models, CGE models (see Kilimani et al., 2015) ${ }^{6}$, partial equilibrium models or qualitative analytical approaches. Irrespective of the modeling technique chosen, the aim is to investigate the effect of a policy variable on other variables away from the baseline.

\footnotetext{
${ }^{6}$ Kilimani et al. (2015) apply a Water-CGE model (UgAGE) to provide a meticulous application of a water tax policy using the proposed framework developed in this paper.
} 
Table 5. Input variables.

\begin{tabular}{|c|c|c|c|}
\hline Sector & $\mathrm{Ipw}^{\mathrm{a}}$ & $\mathrm{Ipo}^{\mathrm{b}}$ & $\operatorname{Inp}^{\mathrm{c}}$ \\
\hline Agriculture & $\begin{array}{l}\text { - Development of WfP } \\
\text { infrastructure }\end{array}$ & $\begin{array}{l}\text { - Irrigation development and expansion } \\
\text { (hectares/p.a.) } \\
\text { - Valley dam infrastructure } \\
\text { development } \\
\text { - Population growth } \\
\text { - Economic growth } \\
\text { - Agricultural patterns and practices }\end{array}$ & $\begin{array}{l}\text { - Unit consumption rates } \\
\text { - Unit employment rates } \\
\text { - Unit production } \\
\text { - Fertilizer use } \\
\text { - Pesticide use } \\
\text { - Water saving due to irrigation } \\
\text { - } \text { use }\left(\mathrm{m}^{3}\right) \\
\text { - Crop productivity }\end{array}$ \\
\hline Households & $\begin{array}{l}\text { - Sewerage treatment } \\
\text { - Domestic water supply }\end{array}$ & $\begin{array}{l}\text { - Net distribution efficiency } \\
\text { - Population growth rate } \\
\text { - Daily household demands }\end{array}$ & $\begin{array}{l}\text { - Water treatment cost }\left(\mathrm{m}^{3}\right) \\
\text { - Sewerage treatment }\left(\mathrm{m}^{3}\right)\end{array}$ \\
\hline Industry & $\begin{array}{l}\text { - Treatment of industrial } \\
\text { effluent }\end{array}$ & $\begin{array}{l}\text { - Industrial growth rate } \\
\text { - Location of industries } \\
\text { - Scale of industrial operations. } \\
\text { - Type of industrial activity }\end{array}$ & $\begin{array}{l}\text { - Net return/ } \mathrm{m}^{3} \\
\text { - Water requirement/unit of } \\
\text { output } \\
\text { - Level of industrialization } \\
\text { - Pollution/unit of output } \\
\text { - Employment/unit of output }\end{array}$ \\
\hline $\begin{array}{l}\text { Hydro- } \\
\text { electricity }\end{array}$ & - Water release for electricity & $\begin{array}{l}\text { - Capacity of hydro-power facility } \\
\text { - Dam size } \\
\text { - Cost of electricity generated }\end{array}$ & $\begin{array}{l}\text { - Technology } \\
\text { - Demand for electricity } \\
\text { - Employment } \\
\text { - Net return/ per unit of power }\end{array}$ \\
\hline Navigation & - Navigable waterways & $\begin{array}{l}\text { - Navigation growth } \\
\text { - Cost of navigation }\end{array}$ & $\begin{array}{l}\text { - Pollution by vessels } \\
\text { - Employment/vessel } \\
\text { - Net return/ vessel }\end{array}$ \\
\hline Water & $\begin{array}{l}\text { - Precipitation harvesting } \\
\text { - Desalination } \\
\text { - Groundwater exploitation } \\
\text { - Surface water exploitation } \\
\text { - Treated waste treatment }\end{array}$ & $\begin{array}{l}\text { - Proportion of return flow from } \\
\text { agriculture } \\
\text { - Proportion of return from households } \\
\text { - Proportion of returns from industrial } \\
\text { water use }\end{array}$ & $\begin{array}{l}\text { - Desalination cost/unit } \\
\text { - Precipitation harvesting cost/ } \\
\text { unit } \\
\text { - Cost of groundwater } \\
\text { exploitation/unit } \\
\text { - Cost of surface water } \\
\text { exploitation/unit } \\
\text { - Cost of wastewater treatment/ } \\
\text { unit }\end{array}$ \\
\hline
\end{tabular}

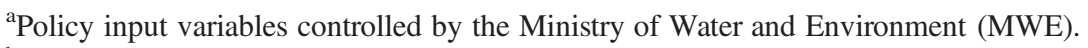

${ }^{\mathrm{b}}$ Policy input variables outside the control of MWE.

${ }^{\mathrm{c}}$ Non-policy input variables.

\section{Conclusion}

In this paper, national water accounts were developed to establish the amount of water available as well as flow into the different sectors of the economy. To link the relevance of water resource accounting to socio-economic policy analysis, the paper proposes a framework which can be used to analyze the link between water policies and the policies of the different sectors. The framework involves the creation of a model structure, identification of the relevant policy variables, the selection of policy evaluation indicators and, finally, undertaking policy simulation. The proposed framework provides an input 
Table 6. Output indicators.

\begin{tabular}{|c|c|c|c|c|}
\hline Sector & $\mathrm{O}_{\mathrm{econ}}^{\mathrm{a}}$ & $\mathrm{O}_{\mathrm{soc}}^{\mathrm{b}}$ & $\mathrm{O}_{\text {env }}^{\mathrm{c}}$ & $\mathrm{O}_{\text {wat }}^{\mathrm{d}}$ \\
\hline Agriculture & $\begin{array}{l}\text { - Sectoral output } \\
\text { - Employment } \\
\text { - Sectoral income }\end{array}$ & $\begin{array}{l}\text { - Food security } \\
\text { - Employment } \\
\text { - Health }\end{array}$ & $\begin{array}{l}\text { - Fertilizer use } \\
\text { - Pesticide use }\end{array}$ & $\begin{array}{l}\text { - Sectoral water } \\
\text { consumption }\end{array}$ \\
\hline Households & $\begin{array}{l}\text { - Water time saved due to } \\
\text { water availability }\end{array}$ & $\begin{array}{l}\text { - Employment } \\
\text { - Health } \\
\text { - Education } \\
\text { outcomes }\end{array}$ & $\begin{array}{l}\text { - Pollution from } \\
\text { households } \\
\text { - Water quality index }\end{array}$ & $\begin{array}{l}\text { - Household water } \\
\text { consumption }\end{array}$ \\
\hline Industry & $\begin{array}{l}\text { - Sectoral output } \\
\text { - Employment } \\
\text { - Sectoral income }\end{array}$ & $\begin{array}{l}\text { - Employment } \\
\text { - Health } \\
\text { - Social amenities } \\
\text { created }\end{array}$ & $\begin{array}{l}\text { - Pollution from industry } \\
\text { - Technologies for } \\
\text { abatement }\end{array}$ & $\begin{array}{l}\text { - Industrial water } \\
\text { consumption } \\
\text { - Water use efficiency }\end{array}$ \\
\hline $\begin{array}{l}\text { Hydro- } \\
\text { electricity }\end{array}$ & $\begin{array}{l}\text { - Sectoral output } \\
\text { - Employment } \\
\text { - Sectoral income }\end{array}$ & $\begin{array}{l}\text { - Employment } \\
\text { - Clean energy } \\
\text { consumption } \\
\text { - Health outcomes }\end{array}$ & $\begin{array}{l}\text { - Pollution impacts } \\
\text { (positive \& negative) }\end{array}$ & $\begin{array}{l}\text { - Sectoral water } \\
\text { requirement }\end{array}$ \\
\hline Navigation & $\begin{array}{l}\text { - Employment } \\
\text { - Contribution to mobility } \\
\text { - Time savings }\end{array}$ & $\begin{array}{l}\text { - Employment } \\
\text { - Ease of mobility }\end{array}$ & - Sectoral pollution & $\begin{array}{l}\text { - Congestion of } \\
\text { waterways }\end{array}$ \\
\hline Water & $\begin{array}{l}\text { - Cost of abstraction and } \\
\text { supply }\end{array}$ & & $\begin{array}{l}\text { - Water resource } \\
\text { exploitation }\end{array}$ & - Water balance \\
\hline
\end{tabular}

${ }^{\mathrm{a}}$ Economic indicators.

${ }^{\mathrm{b}}$ Social indicators.

${ }^{\mathrm{c}}$ Environmental indicators.

${ }^{\mathrm{d}}$ Water availability indicators.

into policy analysis not only for Uganda but for other developing countries as well, whose social and economic activity is highly dependent on water resources availability and management.

The framework is envisaged to provide a useful tool for analyzing the different policy alternatives which have implications for water resources utilization. It allows for active inter-institutional interaction as well as providing feedback regarding the outcomes of different social-economic activities. The main objective is to identify priority actions in line with a country's development plans. Finally, it is critical to note that the proposed framework has been developed as a basis for the analysis of inter- and intra-sectoral linkages between water resource policies and the policies of the other sectors of the economy. It is therefore envisaged that empirical testing based on country or regional specific studies should contextualize this framework. This should be guided by the structure of the economy in question, water resources availability and use, the institutional and policy framework, and the choice of empirical modeling technique. The key aim of this paper is to demonstrate the fact that sound integrated WRM requires robust understanding of the social, economic, and institutional linkages and the water resources.

\section{Policy implications}

The Ugandan economy is currently experiencing water-related challenges emanating from the volatile changes in climate as well as changes in population and economic activity. These changes are 
increasingly putting a strain on the availability of water resources. This paper demonstrates the multiplicity of links between water resources and the economy with a view to highlighting the fact that water as an economic resource needs effective allocation and management. The results from the water accounts show that water consumption within the economy is 4.2 billion $\mathrm{m}^{3}$, with the agricultural sector accounting for an estimated $63 \%$ of consumption. Total water demand stands at approximately $11 \%$ of total water availability. Whereas this figure seems to be low, projections indicate that the country is poised to experience severe water scarcity in the near future. This calls for the need to actively link the water policies with the policies of the other sectors, guided by their development plans. This will be the only sure way of achieving efficient and sustainable use of the existing water resources.

\section{Acknowledgements}

This research was undertaken with financial support from the Carnegie Corporation of New York under the Next Generation of African Academics (NGAA II) project, and Economic Research Southern Africa (ERSA). It is part of a wider thesis research theme which will lead to the award of a Doctor of Philosophy Degree of the University of Pretoria. All errors and omissions are the authors' own.

\section{References}

Awange, J. L. \& Ong'ang'a, O. (2006). Lake Victoria: Ecology, resources, environment. Springer, Berlin, Heidelberg, New York. https://books.google.co.za/books?hl (accessed 31st March 2015).

Awange, J. P., Ogalo, L., Bae, K. H., Were, P., Omondi, P., Omute, P. \& Omullo, M. (2008). Falling Lake Victoria water levels: is climate a contributing factor? Climatic Change 89, 281-297.

Dost, R., Obando, E. B. \& Bastiaanssen, W. (2013). Background report: Water Accounting Plus in the Awash River Basin. www.fao.org/nr/water/docs/awash/ABR5_WaterAccountingPlus.pdf (accessed 1st April 2015).

DWRM (2011). National water resources assessment draft report. Directorate of Water Resources Management, Ministry of Water and Environment-Government of Uganda.

DWRM (2012). Various databases. Directorate of Water Resources Management, Ministry of Water and Environment-Government of Uganda.

Eurostat (2014). Physical water flow accounts (PWFA). http://ec.europa.eu/eurostat/documents/1798247/6664269 (accessed 1st April 2015).

Falkenmark, M. (1984). New ecological approach to the water cycle: ticket to the future. AMBIO 13(3), $152-160$.

Falkenmark, M. \& Widstrand, C. (1992). Population and water resources: A delicate balance. Population Bulletin. Population Reference Bureau, Washington, USA.

FAO (2012). Coping with water scarcity: An action framework for agriculture and food security. FAO Water Report 38, Food and Agriculture Organization of The United Nations, Rome.

FEWSNET. (2012). A Climate Trend Analysis of Uganda: Famine Early Warning Systems Network http://pubs.usgs.gov/fs/ 2012/3062/FS2012-3062.pdf (accessed 25th April 2013).

Glantz, M. H., Gommes, R. \& Ramasamy, S. (2009). Coping with a changing climate: Considerations for adaptation and mitigation in agriculture. Food and Agriculture Organization of the United Nations, Rome.

Hepworth, N. \& Goulden, M. (2008). Climate Change in Uganda: Understanding the implications and appraising the response. LTS International, Edinburgh. Unpublished.

IPCC (2007). Technical summary. In Climate Change 2007: Impacts, Adaptation and Vulnerability. Contribution of Working Group II to the Fourth Assessment Report of the Intergovernmental Panel on Climate Change. Parry, M.L., Canziani, O.F., Palutikof, J.P., van der Linden, P.J., Hanson, C.E. (eds.). Cambridge University Press, Cambridge. 
IWMI (2012). The Nile River Basin: Water, agriculture, governance and livelihoods. Awulachew, S.B., Smakhtin, V., Molden, D., Peden, D. (eds.). International Water Management Institute. www.iwmi.cgiar.org/Publications/Books/PDF/the_nile_river_basin-water_agriculture_governance_and_livelihoods.pdf (accessed 31st March 2015].

Kayombo, S. \& Jorgensen, S. K. (2006). Lake Victoria: Experience and lessons learned brief. www.worldlakes.org/uploads/ 27_Lake_Victoria_27February2006.pdf (accessed 31st March 2015)

Kilimani, N., Van Heerden, J. \& Bohlmann, H. (2015). Water taxation and the double dividend hypothesis. Water Resources and Economics 10, 68-91.

King, N. A. \& Crafford, J. G. (2001). Towards water resource accounts for South Africa for the period 1991 to 1998. Agrekon: Agricultural Economics Research, Policy and Practice in Southern Africa 40(4), 738-754.

Kizza, M., Rhode, A., Xu, Y. C., Ntale, H. K. \& Halldin, S. (2009). Temporal rainfall variability in the Lake Victoria Basin in East Africa during the twentieth century. Theoretical and Applied Climatology 98, 119-135.

LTS International. (2008). Climate Change in Uganda: Understanding the implications and appraising the response. Scoping Mission for DFID Uganda, Kampala, Uganda.

Meadows, D. H., Meadows, D. L. \& Randers, J. (1992). Beyond the Limits. McClelland and Stewart, Toronto, Canada.

MFPED (2011). Background to the Budget for the 2011/12 Fiscal Year. Ministry of Finance Planning and Economic Development-Government of Uganda, Kampala, Uganda.

Miguel, E., Satyanath, S. \& Sergenti, E. (2004). Economic shocks and civil conflict: an instrumental variables approach. Journal of Political Economy 112(4), 725-753.

Molle, F. \& Mollinga, P. (2003). Water poverty indicators: conceptual problems and policy issues. Water Policy 5(5-6), 529-544.

MWE (2009). Strategic Sector Investment Plan for the water and sanitation sector in Uganda, Final Report. Ministry of Water and Environment-Government of Uganda.

NEMA (2010). State of the environment report for Uganda 2010. National Environmental Management Authority (NEMA), Kampala, Uganda. Available at: www.nemaug.org.

NPA (2010). National Development Plan 2010/11-2014/15. National Planning Authority, Kampala, Uganda. http://npa.ug/ docs/NDP_April_2010-Prot.pdf (accessed 7th May 2013).

NWSC (2012). Various Databases. National Water and Sewerage Corporation, Government of Uganda, Kampala, Uganda.

Ngongondo, C. S. (2006). An analysis of long-term rainfall variability, trends and ground water availability in the Mulunguzi river catchment area, Zomba mountain, Southern Malawi. Quaternary International 148, 45-50.

Nsubuga, F. W. N., Olwoch, J. M. \& Rautenbach, C. J. (2011). Climatic trends at Namulonge in Uganda: 1947-2009. Journal of Geography and Geology 3, 119-131.

Nsubuga, F. W. N., Botai, O. J., Olwoch, J. M., Rautenbach, C. J., de, W., Bevis, Y. \& Adetunji, A. O. (2014a). The nature of rainfall in the main drainage sub-basins of Uganda. Hydrological Sciences Journal 59(2), 278-299.

Nsubuga, F., Namutebi, E. \& Nsubuga-Ssenfuma, M. (2014b). Water resources of Uganda: an assessment and review. Journal of Water Resource and Protection 6, 1297-1315.

Nyenje, P. M. \& Batelaan, O. (2009). Estimating the effects of climate change on groundwater recharge and base flow in the upper Sezibwa catchment, Uganda. Hydrological Sciences Journal 54(4), 713-726.

OECD (2008). OECD environmental outlook to 2030. Organization for Economic Co-operation and Development. www.oecd. org/environment/indicators-modelling-outlooks/40200582.pdf (accessed 29th April 2013).

Simonovic, S. P. \& Fahmy, H. (1999). A new modelling approach for water resources policy analysis. Water Resources Research 35(1), 295-304.

Smith, K. A. \& Semazzi, F. H. M. (2014). The role of the dominant modes of precipitation variability over Eastern Africa in modulating the hydrology of Lake Victoria, Advances in Hydrology, Article ID 516762, 11 pages http://dx.doi.org/10.1155/ $2014 / 516762$.

Sutcliffe, J. V. \& Parks, Y. P. (1999). The Hydrology of the Nile. IAHS Special Publication 5, IAHS Press, Wallingford, UK. Swenson, S. \& Wahr, J. (2009). Monitoring the water balance of Lake Victoria, East Africa, from space. Journal of Hydrology $370(1), 163-176$.

UN (1993). SNA Handbook on Integrated Environmental and Economic Accounting. Statistical Office of the United Nations, Series F (No. 61), New York.

UNDESA (2015). World population prospects: The 2012 Revision, Population Division of the Department of Economic and Social Affairs of the United Nations Secretariat http://esa.un.org/unpd/wpp/index.htm (accessed 6th April 2015). 
UNSD (2012). System of environmental-economic accounting for water (SSEA-Water). UN Statistics Division, New York, USA. http://unstats.un.org/unsd/envaccounting/seeaw/seeawaterwebversion.pdf (accessed 4th July 2014).

United Nations, World Bank, OECD. (2003). Integrated environmental and economic accounting: A handbook of national accounting. United Nations, International Monetary Fund, World Bank, and Organization for Economic Co-operation and Development.

Van Steenbergen, F. \& Luutu, A. (2012). Managed groundwater development in Uganda. www.metadata.n1/wordpress/wpcontent/uploads/2012/09/Managed_Groundwater_Development_in_Uganda.pdf (accessed 7th May 2013).

WCED (1987). Our common future. Report of the World Commission on Environment and Development (WCED). Oxford Publishers, UK.

World Bank (2006). Where is the wealth of nations? Measuring capital for the 21st Century. World Bank, Washington DC, USA.

World Bank (2012). Turn down the Heat: Why a $4{ }^{\circ} \mathrm{C}$ warmer world must be avoided. A Report for the World Bank by the Potsdam Institute for Climate Impact Research and Climate Analytics. 


\section{Appendix 1}

\section{Explanatory notes on tables}

Notes on Table 2: the supply table

From surface water (M): imports of surface water.

From surface water $(\mathrm{X})$ : exports of surface water.

From groundwater $(\mathrm{M})$ : import of groundwater.

From groundwater $(\mathrm{X})$ : export of groundwater.

RoW (in transfers): water supply to and from the rest of the world.

Water supply for HEP generation: water supplied to hydro-electricity generation.

DWR: water under jurisdiction of the Directorate of Water Resources. Both commercial and noncommercial supply.

National Water and Sewerage Corporation (NWSC): this is commercially supplied water by the NWSC.

Small Towns Water and Sanitation Programme (STWSP): this is commercial water supplied in other smaller urban centers in the country outside the NWSC supply territory by the Directorate of Water Development (DWD).

S1, S2, S3: these are the sources water supply.

(a) Source (DWRM, 2011), National Water Resources Assessment Draft Report. This value is given as a lump sum volume. The disaggregating by source was done using the FAO (2005) AQUASTAT database. The values by source from FAO (2005) scaled down to yield the lump sum total supply volume provided by the DWRM (2011) study.

(b) RoW is given by (X-M) of surface water flows.

(c) Source (Government of Uganda. Ministry of Water and Environment, Department of WRM (2011) Report, p. 14).

(d) Data from the STWSP under the Department of Water Development, Ministry of Water and Environment (2011).

(e) Commercial water supply data from NWSC (2011).

(f) This is the sum of commercially distributed water by the NWSC and the SWSP. 
(g) Food and Agriculture Organization of the United Nations. (2005) Global Information System on Water and Agriculture [Online]. Available from: www.fao.org/nr/aquastat/ (accessed 22nd February 2013).

(h) Food and Agriculture Organization of the United Nations. (2005) Global Information System on Water and Agriculture [Online]. Available from: www.fao.org/nr/aquastat/ (accessed 22nd February 2013).

(i) Ministry of Water and Environment (2009): Sector Investment Report -Table 1-1 (2015 projections were taken), p. 3.

(j) Ministry of Water and Environment. (2009): Sector Investment Report -Table 1-1 (2015 projections were taken), p. 3.

(k) UN-Water \& Directorate of Water Development (2006) National Water Development Report Table 7.1, p. 118.

(1) UN-Water \& DWD (2006) National Water Development Report-Table 7.2 (2015 projections were taken), p. 121.

(m) Water used for irrigation and, crops as well as one used for electricity generation is taken as water returned to the environment.

Notes on Table 3: the use table

From surface water $(\mathrm{M})$ : imports of surface water.

From surface water $(\mathrm{X})$ : exports of surface water.

From groundwater $(\mathrm{M})$ : import of groundwater.

From groundwater $(\mathrm{X})$ : export of groundwater.

RoW (in transfers): water use by and from the rest of the world.

Water used for HEP generation: water used for hydro-electricity generation.

DWR: total distributed water both for NWSC and the STWSP.

NWSC: this is commercially supplied water by the NWSC.

STWSP: this is commercial water supplied in other smaller urban centers in the country outside the NWSC supply territory.

$\mathrm{U} 1, \mathrm{U} 2, \mathrm{U} 3$ : these are the uses of water supply.

(a) Total $=$ surface water $(90 \%)$ and groundwater $(10 \%)$ based on the design consumption rates in Table 4.8 (Government of Uganda. Ministry of Water and Environment, Department of WRM (2011), National Water Resources Assessment Draft Report, p. 96).

(b) Government of Uganda. Ministry of Water and Environment, Department of WRM (2011), National Water Resources Assessment Draft Report, p. 98.

\section{References}

DWRM (2011). National water resources assessment draft report. Directorate of Water Resources Management, Ministry of Water and Environment-Government of Uganda.

Food and Agriculture Organization of the United Nations (2005). Global Information System on Water and Agriculture [Online]. Available from: www.fao.org/nr/aquastat/ (accessed 22nd February 2013).

UN-Water \& DWD (2006). National water development report. A UN-Water and World Water Assessment Program report prepared for the 2nd UN World Water Development Report 'Water, a shared responsibility'. Available from: http:// unesdoc.unesco.org/images/0014/001467/146760e.pdf (accessed 15th April 2013). 